\title{
MEDIALNE I SPOLECZNE DOMNIEMANIE WINY A PRAWNE DOMNIEMANIE NIEWINNOŚCI (SPOJRZENIE PRAWNE A NOWA PERSPEKTYWA)
}

\begin{abstract}
Streszczenie. Tematem artykułu są rozważania, które dotyczą obowiązującego w prawie karnym domniemania niewinności oraz domniemania winy, które może powstać w środkach masowego przekazu, a tym samym w opinii publicznej. Omówione zostały rozwiązania prawne w prawie karnym, prawie prasowym, prawie międzynarodowym, które mają przeciwdziałać tworzeniu fałszywego obrazu procesów. Ponadto wskazano na orzecznictwo sądowe, które stawia wymogi do rzetelnego informowania o przebiegu postępowań przygotowawczych i sądowych, a także zwrócono uwagę na szczególne obowiązki rzeczników prasowych.

Słowa kluczowe: zasada domniemania niewinności, medialne domniemanie winy, społeczne domniemanie winy, podejrzany, osoba podejrzana, oskarżony, skazany, prawomocny wyrok skazujący.
\end{abstract}

\section{WSTĘP}

Rosnąca rola mediów w życiu publicznym, w kształtowaniu świadomości prawnej ${ }^{1}$ oraz informowaniu o działalności organów ścigania, ponadto wymiaru sprawiedliwości skłania do poczyninia uwag dotyczacych jednej z podstawowych zasad określających status jednostki w państwach demokratycznych (Garlicki 2003, 1) - zasady domniemania niewinności [zasady nullum crimen (nulla poena) sine lege anteriori] rozumianej w procedurze karnej oraz jako skutku formy przekazu informacji na tle konkretnych spraw ${ }^{2}$. Chodzi przede wszystkim o wskazanie na czym polega domniemanie niewinności w prawie karnym procesowym i jak rozumiane jest ono w odbiorze społecznym, który kształtowany jest poprzez rzeczników prasowych organów ścigania oraz dziennikarzy w środkach masowego przekazu.

"Prokurator Prokuratury Regionalnej w Lodzi, kalifornia1@wp.pl.

${ }^{1}$ Świadomość prawna ma znaczenie nie tylko w zakresie wiedzy społeczeństwa o prawie, ale także w zakresie skuteczności prawa karnego, bowiem im jest ta świadomość większa, tym prawo karne jest skuteczniejsze (Marek, Konarska-Wrzosek 2019, 15).

${ }^{2}$ Ograniczenie zasady domniemania niewinności do prawa karnego procesowego związane jest z omawianą problematyką informacyjną, która dotyczy głównie przekazu informacji o podejmowanych czynnościach procesowych przez organy ścigania. 
Punktem wyjścia w toku rozważań jest przedstawienie zagadnienia zasady domniemania niewinności w wybranym orzecznictwie sądowym, a więc wskazania jak ta zasada rozumiana jest $\mathrm{w}$ prawie polskim oraz międzynarodowym $\mathrm{i}$ w jakim zakresie możliwe jest przekazanie informacji z toczącego się postępowania przygotowawczego społeczeństwu. W toku rozważań zwrócono uwagę na kwestie prawdy w rozumieniu filozoficznym, która winna być także podstawą wszelkich ustaleń w prowadzonych postępowaniach. Zasada domniemania niewinności jest skierowana do odbiorcy w rozumieniu społeczeństwa i dlatego jej dochowanie leży w gestii rzeczników prasowych oraz dziennikarzy. Praktyczny wymiar zasady domniemania niewinności kształtowany jest w odbiorze społecznym przekazywanych informacji. Realizacja zasady domniemania niewinności odbywa się w znacznym zakresie na płaszczyźnie nowych narzędzi do formowania osądów. Stąd ważne jest zestawienie zasady domniemania niewinności w prawnym znaczeniu z medialnym i społecznym skutkiem.

\section{POJECIE DOMNIEMANIA NIEWINNOŚCI W PRAWIE KARNYM PROCESOWYM}

Zasada domniemania niewinności jest jedną z podstawowych zasad konstytucyjnych prawa karnego procesowego ${ }^{3}$. Została ona wyrażona w art. $5 \S 1$ kodeksu postępowania karnego, który stanowi, że ,[o]skarżonego uważa się za niewinnego, dopóki wina jego nie zostanie udowodniona i stwierdzona prawomocnym wyrokiem". W swojej istocie oznacza, że do czasu prawomocnego orzeczenia sądowego każda osoba uważana jest za osobę niewinną. Jest więc związana z sądem, jako organem wymiaru sprawiedliwości ${ }^{4}$. Prawidłowo rozumiana dotyczy także organów ścigania i wszystkich tych, którzy wypełniają zadania informacyjne wobec społeczeństwa. Sięgając do początku kształtowania się tej zasady trzeba wskazać, że wprawdzie jej historia jest długa, ale nie zawsze zasada ta była uznawana i stosowana w praktyce. Obecnie zasada domniemania niewinności oznacza ustawowe żądanie, aby do czasu prawomocnego stwierdzenia winy oskarżonego uważać go za niewinnego i odpowiednio go traktować (Boratyńska, Górski, Sakowicz, Ważny 2009, 22). Z postanowienia Sądu Apelacyjnego w Krakowie z 29.11.1999 r., II AKz 537/99, wynika, że „[w]yciąganie wniosków niekorzystnych dla skazanego (dla kogokolwiek) z faktu wniesienia przeciw niemu oskarżenia o przestępstwo narusza domniemanie niewinności (art. 42 ust. 1 Konstytucji i art. $5 \S 1$ k.p.k.) .

\footnotetext{
${ }^{3}$ Zasada domniemania niewinności została umieszczona w Konstytucjach wielu państw (Garlicki 2003, 1).

${ }^{4}$ Ustawa z 6.06.1997 r. Kodeks postępowania karnego - t.j. z 14.09.2018 r., Dz.U. z 2018 r., poz. 1987.

${ }^{5}$ Post. SA w Krakowie z 29.11.1999 r., II AKz 537/99, KZS 1999, nr 12, poz. 25, za: Boratyńska, Górski, Sakowicz, Ważny $(2009,24)$. Bliżej o zasadzie domniemania niewinności: Bojarski (2011, 481 i n.).
} 
Zasada domniemania niewinności jest więc zasadą konstytucyjną (Garlicki 2003, 6-7) ${ }^{6}$. Nie budzi wątpliwości, że zasada domniemania niewinności obowiązuje do chwili wydania prawomocnego wyroku uznającego winę (Świecki 2013, 47). Jest kierowana do każdego, kto miałby dopuścić się czynu zabronionego (Garlicki 2003, 7). Jeżeli chodzi o etap wznowienia postępowania lub kasacji, to tutaj już powstają wątpliwości co do stosowania zasady domniemania niewinności i część autorów opowiada się za uznaniem, że nieuprawnione jest przyjmowanie obowiązywania zasady domniemania niewinności, ponieważ postępowania te mogą się toczyć po wydaniu prawomocnego orzeczenia (Świecki 2013, 47, tak samo Paprzycki 2013, 59). Zasada domniemania niewinności odżywa na nowo w momencie uchylenia prawomocnego orzeczenia skazującego (Świecki 2013, 47). Trzeba także podkreślić, że obowiązuje ona przez cały czas prowadzenia postępowania po wydaniu prawomocnego wyroku uniewinniającego, a to z tego względu, że domniemanie niewinności nigdy nie zostało w toku tego postępowania obalone (Świecki 2013, 47).Zasada domniemania niewinności nie obowiązuje w przypadku uchylenia orzeczenia tylko w zakresie orzeczenia co do kary, bowiem kwestia uznania winy w takim orzeczeniu sądu odwoławczego została już prawomocnie przesądzona i jest dla sądu, który będzie ponownie się sprawą zajmował, wiążąca (Świecki 2013, 47). Słusznie w doktrynie reprezentowany jest pogląd, że zasada domniemania niewinności winna być przyjmowana w toku postępowania ekstradycyjnego, Europejskiego Nakazu Aresztowania, ponieważ orzeczenia wydawane w tych procedurach nie są orzeczeniami stwierdzającymi winę (Świecki 2013, 47). Mówiąc o wyroku stwierdzającym winę należy także mieć na uwadze wyrok warunkowo umarzający postępowanie (Świecki 2013, 47). Trzeba także wskazać, co nie zawsze jest podnoszone, że zasada domniemania niewinności dotyczy zarówno wątpliwości natury faktycznej jak i prawnej (Paprzycki 2013, 60)․

\section{OSOBA PODEJRZANA, PODEJRZANY, OSKARŻONY, SKAZANY}

Jak już wcześniej zostało dowiedzione, domniemanie niewinności funkcjonuje do czasu prawomocnego skazania, a więc osoby skazanej, z zastrzeżeniem, że chodzi o skazanego prawomocnym wyrokiem. Oznacza to, że obowiązuje ona również osobę, którą podejrzewa się o popełnienie czynu zabronionego, a nawet osobę, co do której nie wyklucza się, że mogła taki czyn zabroniony popełnić (Garlicki 2003, 7). Na etapie po wydaniu postanowienia o wszczęciu postępowania przygotowawczego, w procedurze karnej występuje „osoba podejrzana”, ,podejrzany”, „oskarżony” oraz „skazany”, przy czym należy zastrzec, że określenie

${ }^{6}$ Bliżej odnośnie zasady domniemania niewinności: Safjan, Bosek (2016, 1006 i n.); Dukiet-Nagórska $(2018,76)$.

${ }^{7}$ Nieco inaczej przyjął SN w wyr. z 6.12.2006 r., III KK 181/06 (OSNKW 2007, nr 2, poz. 16). 
„skazany" może odnosić się do skazania nieprawomocnego oraz skazania prawomocnego. Z uwagi na to, że domniemanie niewinności ustaje wobec „skazanego” prawomocnym orzeczeniem, warto zwrócić uwagę na istotę wskazanych wyżej pojęć, ich rozumienie w kontekście prawidłowej realizacji zasady domniemania niewinności.

Na wstępie trzeba wskazać, że już kodeks postępowania karnego z $1928 \mathrm{r} .^{8}$ rozróżniał osobę podejrzaną od podejrzanego, czego przykładem jest art. 78 $\S 1$ k.p.k., a ponadto art. 137 § 1 k.p.k. Również w kodeksie postępowania karnego z 1969 r. ${ }^{9}$ instytucja podejrzanego została odróżniona od instytucji osoby podejrzanej, co wynikało z art. $61 \S 1$ k.p.k. w zestawieniu z art. $206 \S 1$ k.p.k. Podstawą do podejmowania pewnych czynności związanych z gromadzeniem materiału dowodowego do osoby, co do której nie wydano postanowienia o przedstawieniu zarzutów, był art. 267 k.p.k., który pozwalal na czynności wymienione w art. 65 $\S 1 \mathrm{pkt} 1 \mathrm{w}$ stosunku do osoby podejrzanej (podkreślenie własne - K.P.), a także dokonanie innych niezbędnych czynności, nie wyłączając pobrania próby krwi i wydzielin. Obecnie czynności te można wykonać w ramach dochodzenia w niezbędnym zakresie na podstawie art. 308 k.p.k. ${ }^{10}$.

Trzeba jednak zwrócić uwagę na art. 74 § 3 i $\S 3 a$ k.p.k., który jest umieszczony w rozdziale 8 kodeksu postępowania karnego i dotyczy obowiązków dowodowych oskarżonego, podejrzanego oraz osoby podejrzanej (podkreślenie własne - K.P.). Osoba podejrzana ma poddać się pewnym badaniom oraz czynnościom. Trzeba wyraźnie wskazać, że osoba podejrzana znajduje się w specyficznej sytuacji procesowej, bo nie jest stroną procesu (Skorupka 2015, 259). Jednocześnie z uwagi na to, że jest osobą podejrzaną (nie podejrzanym - podkreślenie własne - K.P.), ma obowiązek poddać się pewnym czynnościom oraz badaniom, a w razie odmowy od 9.11.2013 r. możliwe jest zastosowanie wobec niej przymusu. Istota tego rozwiązania oraz wskazanego w art. 192a k.p.k. sprowadza się do stosowania pewnych ograniczeń do jeszcze nie podejrzanych, ale osób podejrzanych, właśnie z racji tego statusu osoby podejrzanej, w ramach gromadzenia materiału dowodowego oraz w celu eliminacji z kręgu podejrzanych. Ustawodawca doszed do wniosku, że nałoży pewne ciężary i ograniczenia, nawet przy zastosowaniu przymusu, po pierwsze, w celach dowodowych ${ }^{11}$, a po drugie, $w$ celu eliminacji

\footnotetext{
${ }^{8}$ Kodeks postępowania karnego z 19.03.1928 r. - t.j. Dz.U. 1949.33.243 ze zm.

${ }^{9}$ Ustawa z 19.04.1969 r. - Kodeks postępowania karnego - Dz.U. z 14.05.1969 r. - Dz.U. 1969.13.96.

${ }^{10}$ Ustawa z 6.06.1997 r. Kodeks postępowania karnego - t.j. - Dz.U. 2018.1987.

${ }^{11}$ Należy wyraźnie podkreślić, że chodzi o cele dowodowe, które związane są z gromadzeniem dowodów i musi się to odbywać w granicach wyznaczonych kwalifikacją prawną czynów, co do których prowadzone są czynności dowodowe. Jako sprzeczne z prawem należy uznać takie czynności, które pozostają poza zakresem prowadzonego postępowania, kiedy czynności te zmierzają do zgromadzenia materiału dowodowego w poszukiwaniu jakichkolwiek śladów na rzekome popełnienie czynu zabronionego lub zmierzających do uwikłania w długotrwałe postępowanie przygotowawcze.
} 
z kręgu podejrzanych, po to, aby nie wydawać pochopnie postanowień o przedstawieniu zarzutów. Z powyższego jednoznacznie wynika, że konstrukcja „osoby podejrzanej" wprowadzona została w celach gwarancyjnych, związanych z nałożeniem pewnych obowiązków, zamiarem wyeliminowania pochopnego wydawania postanowień o przedstawieniu zarzutów. Dopiero od momentu wydania postanowienia o przedstawieniu zarzutów możliwe jest przyjęcie, że dana osoba jest podejrzana. Wówczas mówimy o podejrzanym.

W procedurze karnej funkcjonuje jeszcze pojęcie „oskarżony”, za którego uważa się osobę, co do której wniesiony został akt oskarżenia do sądu ${ }^{12}$. Trzeba jasno wskazać, że zasada domniemania niewinności nie oznacza tego, że wobec osoby podejrzanej, podejrzanego czy też oskarżonego nie można wykonywać czynności, które są prawem przewidziane. Nie chodzi tutaj też o subiektywne przekonanie organu prowadzącego postępowanie, że dana osoba jest niewinna. Chodzi o to, aby w sposób przewidziany prawem wykonywać czynności, które doprowadzą do ostatecznego stwierdzenia w prawomocnym wyroku niewinności lub winy oskarżonego. Trzeba jednak zastrzec, że chodzi o czynności realizowane we właściwej procedurze przez uprawniony do ich wykonania organ. Dlatego też bez przełamania zasady domniemania niewinności możliwe jest stosowanie wobec podejrzanego tymczasowego aresztowania, które, co należy podkreślić, nie obala domniemania niewinności (Grzegorczyk 2014, 61). Obalenie domniemania niewinności następuje bowiem dopiero przez wydanie prawomocnego wyroku stwierdzającego winę oskarżonego (Grzegorczyk 2014, 47).

Uwagi te mają zasadnicze znaczenie dla praktycznego przestrzegania zasady domniemania niewinności.

\section{DOMNIEMANIE NIEWINNOŚCI W AKTACH PRAWA MIĘDZYNARODOWEGO}

Zasada domniemania niewinności stanowi również jedną z fundamentalnych zasad dotyczacych podstawowych praw człowieka. Została umiejscowiona we francuskiej Deklaracji praw człowieka i obywatela z 1789 r. (Garlicki 2003, 1). Znalazła się w Powszechnej Deklaracji Praw Człowieka ONZ, gdzie w art. 11 ust. 1 wskazano, iż „,[k]ażdy człowiek oskarżony o popełnienie przestępstwa ma prawo, aby uznawano go za niewinnego dopóty, dopóki nie udowodni mu się winy zgodnie z prawem podczas publicznego procesu, w którym zapewniono mu wszystkie konieczne środki obrony"'13. Ponadto, zgodnie z art. 14 ust. 2 Międzynarodowego Paktu Praw Obywatelskich i Politycznych, otwartego do podpisu w Nowym Jorku

${ }^{12}$ Samo wniesienie aktu oskarżenia nie przesądza o winie. Jest tylko skargą, która wniesiona jest przez uprawnionego oskarżyciela, która podlega rozpoznaniu przez sąd.

${ }^{13}$ Powszechna Deklaracja Praw Człowieka, uchwalona 10.12.1948 r. na Trzeciej Sesji Ogólnej Zgromadzenia ONZ; http://www.unesco.pl/fileadmin/user_upload/pdf/Powszechna_Deklaracja Praw_Czlowieka.pdf [dostęp: 30.05.2019]. 
19.12.1966 r., każda osoba oskarżona o popełnienie przestępstwa ma prawo być uważana za niewinną aż do udowodnienia jej winy zgodnie z ustawą ${ }^{14}$.

Również Konwencja o Ochronie Praw Człowieka i Podstawowych Wolności, sporządzona w Rzymie 4.11.1950 r., zmieniona następnie Protokołami nr 3, 5 i 8 oraz uzupełniona Protokołem nr 2, wymienia w art. 6 ust. 2 zasadę domniemania niewinności jako zasadę wchodzącą w skład prawa do rzetelnego procesu sądowego ${ }^{15}$. Zgodnie w tym przepisem ,[k]ażdego oskarżonego o popełnienie czynu zagrożonego karą uważa się za niewinnego do czasu udowodnienia mu winy zgodnie z ustawą" ${ }^{\prime \prime}$. Zasada ta uznana została nie tylko jako gwarancja procesowa w postępowaniu karnym, ale uznano także, że jest ona adresowana do organów i funkcjonariuszy państwowych, co wynika chociażby z decyzji Komisji Petra Krauze v. Szwajcarii ${ }^{17}$. Zgodnie z wyrokiem ETPC z 25.03.1983 r., 8660/79, Minelli przeciwko Szwajcarii, Trybunał przyjął, że zasada domniemania niewinności dotyczy także postępowań poprzedzających procedurę sądową ${ }^{18}$. Istotne dla czynionych rozważań jest także i to, że naruszenie zasady domniemania niewinności powiązane zostało z poszanowaniem honoru oraz godności osoby, która jest ścigana ${ }^{19}$. Natomiast godność została powiązana z bezpieczeństwem jednostki (Krztoń 2018, 15 i n.). Odnosząc się do treści wypowiedzi, które mogą naruszać zasadę domniemania niewinności należy stwierdzić, że - zgodnie z orzecznictwem ETPC -winny one być pozbawione ocen i w żadnym razie nie mogą przesądzać o winie ${ }^{20}$. Możliwe jest także informowanie o treści orzeczenia sądu pierwszej

${ }^{14}$ Międzynarodowy Paktu Praw Obywatelskich i Politycznych, otwarty do podpisu w Nowym Jorku 19.12.1966 r. - Dz.U. z 29.12.1977 r. - Dz.U. 1977.38.167. zał.

${ }^{15}$ Konwencja o Ochronie Praw Człowieka i Podstawowych Wolności, sporządzona w Rzymie 4.11.1950 r., zmieniona następnie Protokołami nr 3, 5 i 8 oraz uzupełniona Protokołem nr 2 (Dz.U. z 10.07.1993 r., Dz.U. 1993.61.284).

${ }^{16}$ Konwencja o Ochronie Prawa Człowieka i Podstawowych Wolności, sporządzona w Rzymie 4.11.1950 r., http://prawo.sejm.gov.pl/isap.nsf/download.xsp/WDU19930610284/O/D19930284.pdf [dostęp: 30.05.2019].

${ }^{17}$ Decyja Komisji Petra Krauze v. Szwajcaria z 3.10.1978 r., skarga nr 7986/77, DR 13/73, za: Nowicki $(2013,611)$.

${ }^{18}$ Wyr. ETPC z 25.03.1983 r., 8660/79, Minelli przeciwko Szwajcarii, za: Skorupka $(2015,24)$; LEX nr 80843. Stan faktyczny tej sprawy dotyczył zniesławienia w związku z publikacją prasową przez oskarżonego, który opublikował informacje podobne do opublikowanych przez inną osobę, która została uznana za winnego. Sąd orzekający w sprawie - w zakresie uznania winy - nie poczynił ustaleń w tym zakresie, a oparł się tylko na tych ustaleniach, które zostały poczynione w innej sprawie. Europejski Trybunał Praw Człowieka doszedł do wniosku, iż doszło do naruszenia domniemania niewinności, ponieważ oskarżonemu nie została - zgodnie z prawem - udowodniona wina, a ponadto został on - poprzez takie postępowanie sądu - pozbawiony prawa do obrony. Tak samo: Garlicki $(2003,7)$.

${ }^{19}$ Wyr. Konstas v. Grecja z 24.05.2011 r., Izba (Sekcja I), skarga nr 53466/07, za: Nowicki $(2013,612)$.

${ }^{20}$ Decyzja Komisja X. v. Holandia z 17.12.1981 r., skarga nr 8361/78, DR 27/37, wyr. Y.B. i inni v. Turcja z 28.10.2004 r., Izba (Sekcja III), skarga nr 48173/99 i 48319/99, §§ 47-48, za: Nowicki $(2013,614)$. 
instancji pomimo tego, że apelacja nie została jeszcze rozpoznana ${ }^{21}$. Trzeba także zaznaczyć, że relacje z procesów należy rozpatrywać również jako zakaz tortur, co wynika z orzecznictwa Europejskiego Trybunału Praw Człowieka ${ }^{22}$.

Zasada domniemania niewinności została także wprowadzona do Karty Praw Podstawowych Unii Europejskiej, w której art. 48 wskazuje, że każdego oskarżonego uważa się za niewinnego, dopóki jego wina nie zostanie stwierdzona zgodnie z prawem (Wróbel 2013, 1253). Zasada ta ma charakter bezwzględny, co wyklucza jakiekolwiek jej obchodzenie, przykładowo w formie aluzji ${ }^{23}$.

\section{DOMNIEMANIE NIEWINNOŚCI W PRAWIE PRASOWYM}

Domniemanie niewinności w prawie prasowym nie zostało wyrażone wprost. Można je jednak wywodzić z poszczególnych przepisów prawa prasowego, w pierwszej kolejności z art. 13 ust. 1 prawa prasowego zakazującego wypowiadania opinii co do rozstrzygnięcia w postępowaiu sądowym przed wydaniem orzeczenia w pierwszej instancji oraz tych, które odnoszą się do rzetelnego informowania, jawności życia publicznego oraz kontroli i krytyki społecznej ${ }^{24}$. W szczególności chodzi tutaj o wskazane w art. 6 ust. 1 Prawa prasowego zobowiązanie do prawdziwego przedstawienia omawianych zjawisk ${ }^{25}$. Jednocześnie w dotarciu do prawdy nałożone są ustawowe obowiązki na inne podmioty, które polegają przykładowo na udzielaniu - nie później niż w ciągu miesiąca - informacji przez organy państwowe, przedsiębiorstwa państwowe i inne państwowe jednostki organizacyjne oraz organizacje spółdzielcze ${ }^{26}$. Ponadto nałożony został

${ }^{21}$ Decyzja Komisji F. i S. F. v. Austria z 7.10.1985 r., skarga nr 10847/84, DR 44/238, za: Nowicki $(2013,615)$.

${ }^{22}$ Nowicki (2013, 413-414), gdzie uznał, że pokazanie oskarżonego w kajdankach na rozprawie, nawet jeżeli nie miało na celu upodlenia i poniżenia, to było poniżającym traktowaniem; wyr. z 20.01.2011 r., Izba (Sekcja V), skarga nr 891/05. Tak samo umieszczenie w klatce otoczonej przez dużą liczbę funkcjonariuszy oskarżonego i transmitowanie tej rozprawy na cały kraj jest zbyt dolegliwe i poniżające i narusza art. 3 Europejskiej Konwencji Praw Człowieka. W sprawie Ashot Harutynyan Trybunał uznał, że tak drastyczny obraz rozprawy sądowej mógł prowadzić przeciętnego widza do przekonania, że chodzi o wyjątkowo niebezpiecznego przestępcę. W rezultacie poniżał oskarżonego, jeśli nie w oczach opinii publicznej, to w jego własnych oczach; wyr. z 27.01.2009 r., Izba (Sekcja IV), skarga nr 1704/06, $\S \S 99-102$; wyr. Ashot Harutynyan przeciwko Armenii z 15.06.2010 r., Izba (Sekcja III), skarga nr 34334/04, §§ 126-129, wyr. Pizuryna przeciwko Armenia z 26.06.2012 r., Izba (Sekcja III), skarga nr 33376/07, §§ 70-72).

${ }^{23}$ Wyr. SPI z 6.10.2005 r., T-22/02 oraz T-23/02, Sumitomo Chemical Co. Ltd. i Sumika Fine Chemicals Co. Ltd. przeciwko Komisji Wspólnot Europejskich, Zb. Orz. 2005, II-4065, pkt. 106107, za: Wróbel $(2013,1261)$.

${ }^{24}$ Ustawa z 26.01.1984 r. Prawo prasowe - t.j. Dz.U. 2018.1914.

${ }^{25}$ Ustawa z 26.01.1984 r.

${ }^{26}$ Obowiązek przekazywania informacji wynika z art. 6 ust. 2 Prawa prasowego. 
ustawowy zakaz utrudniania prasie zbierania materiałów krytycznych lub tłumienia krytyki w inny sposób ${ }^{27}$. Za słuszny zatem należy uznać pogląd, że media i społeczeństwo są adresatem zasady domniemania niewinności (Safjan, Bosek 2016, 1067).Trzeba podkreślić, że szczególne ważne obowiązki związane z realizacją zasady domniemania niewinności spoczywają na rzecznikach prasowych instytucji, w tym w szczególności reprezentujących organy ścigania. Jest to związane z prawidłową realizacją zasady domniemania niewinności już na pierwszym etapie czynności wykonywanych przez organy ścigania, zarówno przed wydaniem postanowienia o wszczęciu postępowania przygotowawczego, jak i po wydaniu tegoż postanowienia. $Z$ jednej strony rzecznicy prasowi mają prawo do informowania opinii publicznej o toczących się postępowaniach ${ }^{28}$, dziennikarze pozostają pod presją opinii publicznej odnośnie udzielenia informacji z toczącego się postępowania, a z drugiej strony przekazywane informacje muszą być wyważone tak, aby nie naruszyły zasady domniemania niewinności. Przykładowo należy wskazać, że jako naruszające tę zasadę uznana została zbyt intensywna kampania prasowa ${ }^{29}$. W prawie prasowym domniemanie niewinności powiązane jest - w przypadku jego naruszenia - ze zniesławieniem osoby, której informacje dotyczą. Jak pisze W. Kulesza, nie istnieje „immunitet dziennikarski”, który chroniłby dziennikarza przed odpowiedzialnością karną za zniesławienie (Kulesza 2012, 1040). Ważne jest, aby dziennikarz dochował należytej staranności w gromadzeniu materiałów, a ponadto przedstawił je zgodnie z prawdą (Kulesza 2012, 1040). Nie można jednak nie zauważyć zależności od informacji, jakie przekazywane są przez rzeczników prasowych organów ścignia od sytuacji, kiedy materiał został samodzielnie opracowany przez dziennikarza. W pierwszym przypadku zależność ta wynika z rodzaju przekazanych informacji oraz praktycznym zakazie dostępu do akt sprawy, a w drugim przypadku w relacji do organów ścigania w zakresie głównie dostępu do akt sprawy. W obu wypadkach obowiązek realizacji zasady domniemania niewinności jest równie ważny, przy czym jego ciężar podmiotowy jest inaczej rozłożony. Przy praktycznej realizacji zasady domniemania niewinności chodzi również o ochronę godności zewnętrznej człowieka w postaci jego dobrej sławy, którą posiada w społeczeństwie i która jest związana z przynależną mu i przyrodzoną godnością osobowościową. Trzeba także zaznaczyć, że z tymi wartościami powiązane jest prawo do wolności słowa, rozumiane jako prawo do otrzymania zgodnej z prawdą informacji. Nikt nie może bronić się przed zarzutem zniesławienia, jeżeli podaje nieprawdziwe informacje. Uwolnienie od odpowiedzialności karnej może nastapić na podstawie art. 213 Kodeksu

${ }^{27}$ Zakaz ten wynika $\mathrm{z}$ art. 6 ust. 4 Prawa prasowego.

${ }^{28}$ Orzeczenie Allenet de Ribemont v. Francja z 10.02.1995 r., A. 308, par. 38, za: Nowicki $(1999,280)$.

${ }^{29}$ Przykładowo sprawa Beelen v. Belgia z 24.02.1997 r., skarga nr 25470/94, nie publ., za: Nowicki $(1999,280)$. 
karnego ${ }^{30}$, przy czym podstawowym warunkiem, zarówno przy publicznym, jak i niepublicznym pomówieniem jest wykazanie prawdziwości uczynionego zarzutu. Trzeba zastrzec, że publiczne poczynienie zarzutu osobie pełniącej funkcję publiczną, do uznania, że nie doszło do popełnienia przestępstwa, wymaga tylko wykazania prawdziwości zarzutu. W pozostałych wypadkach uczynienia zarzutu innym osobom, grupie osób, osobom prawnym lub jednostkom organizacyjnym nie posiadającym osobowości prawnej, jest poza wykazaniem prawdziwości zarzutu, wykazanie, że informacja służy społecznie uzasadnionemu interesowi ${ }^{31}$. Jak bowiem orzekł Sąd Najwyższy w wyroku z 6.06.2006 r., IV KK 87/06, na dziennikarzu ciąży obowiązek i odpowiedzialność 32 .

\section{POZIOMY MEDIALNEGO I SPOLECZNEGO DOMNIEMANIA WINY}

W opozycji do wskazanej wyżej istoty zasady domniemania niewinności można wskazać, iż domniemanie winy oznacza, że z góry, bez prawomocnego orzeczenia sądu uważa się, że sprawcą czynu zabronionego jest osoba wskazana jako ta, która dopuściła się zachowania nagannego, ale w rozumieniu potocznym. Dlatego domniemanie winy może być kształtowane na kilku poziomach. $\mathrm{Na}$ wszystkich tych poziomach winna obowiązywać hermeneutyka prawa ${ }^{33}$. Pierwszym i podstawowym z nich jest komunikowanie o czynnościach procesowych związanych z różnymi etapami postępowań w sposób, który zakłada domniemanie winy. Bez zastrzeżenia, że jest to etap gromadzenia materiału dowodowego, może powstać u odbiorcy wyobrażenie skierowania postępowania przeciwko określonej osobie, a więc w odczuciu społecznym domniemanie winy. Można przyjąć, że zamierzone wykonywanie obowiązków informacyjnych jest formą manipulacji informacją, która zmierza do społecznego potępienia określonej osoby, zanim uczyni to sąd w prawomocnym orzeczeniu. Jest także formą wkraczania w kompetencje sądu i marginalizacji jego roli w procesie wymiaru sprawiedliwości.

Jako formę domniemania winy należy wskazać niejasne informowanie o przeprowadzonych czynnościach procesowych, tak jakby sam fakt przeprowadzenia określonej czynności procesowej tworzył podstawę do domniemania winy. Przykłady dotyczą czynności, które są związane z gromadzeniem materiału

${ }^{30}$ Ustawa z 6.06.1997 r. Kodeks karny, t.j. - Dz.U. 2018, poz. 1600 ze zm.

${ }^{31}$ Artykuł $213 \S 2$ Kodeksu karnego.

${ }^{32}$ Wyr. SN z 6.06.2006 r., IV KK 87/06, OSNKW 2006, nr 10, poz. 91, powołany przez W. Kuleszę za: Warylewski $(2012,1040)$.

${ }^{33}$ Zajadło (2018, 112-113), gdzie autor wskazuje, że określnie hermeneutyka powiązane jest z greckim bogiem Hermesem, który miał obwieszczać decyzje bogów ludziom. Hermeneutyka pojawiła się także u Arystoytelesa, który w Organonie jeden z rozdziałów poświęcił interpretacji. Stąd obecnie hermeneutyka rozumiana jako tłumaczenie, objaśnianie, przekład. 
dowodwego, przy czym dotyczy to dokonywania czynności zabezpieczania dokumentacji działalności gospodarczej, dokumentacji związanej z funkcjonowaniem urzędu lub instytucji. W odbiorze społecznym, bez zastrzeżenia, że czynności są niezbędne dla wyjaśnienia sprawy, sam fakt przeprowadzania danej czynności w określonym miejscu odczytany może być jako zawinienie osoby fizycznej lub osób fizycznych zatrudnionych w danym podmiocie gospodarczym lub instytucji. Naruszenie zasady domniemania niewinności ma szczególnie dotkliwe skutki przy tzw. „przestępczości gospodarczej”, zwłaszcza w stanach kryzysów, gdzie oczekiwane jest wręcz natychmiastowe wydanie ,wyroku prasowego”. Nadzwyczaj negatywne i nieodwracalne skutki mogą dotykać wszystkich tych instytucji, gdzie do wykonywania zadań niezbędne jest zaufanie społeczne do ich zgodnego funkcjonowania $\mathrm{z}$ prawem.

Społeczne domniemanie winy może być wywoływane także poprzez niewłaściwe, w rozumieniu nieproporcjonalne, stosowanie środków przymusu, które dotyczą przykładowo zatrzymania, gdy brak jest ku temu podstaw prawnych lub faktycznych ${ }^{34}$. W opinii społecznej stosowanie środków zapobiegawczych takich jak areszt tymczasowy, bądź środki wolnościowe, odbierane jest jako zawinienie osoby, do której środki te są stosowane. Dlatego istotne winno być jednoczesne informowanie o tym, że zastosowany środek ma zabezpieczyć tok prowadzenia postępowania przygotowawczego i nie przesądza o winie osoby, co do której środek jest stosowany.

Kolejnym etapem jest niejasne informowanie o rodzaju zarzucanego wskazanemu sprawcy czynu zabronionego w oderwaniu od znamion czynu wskazanego w odpowiednim przepisie prawa. Chodzi przede wszystkim o posługiwanie się słownictwem pozyskanym $z$ treści postanowienia o przedstawieniu zarzutów bez wyjaśnienia istoty czynu zabronionego i elementów niezbędnych do przypisania popełnienia tego czynu wskazanej osobie. U odbiorcy rodzi to pytanie o istotę naruszonego przepisu prawa karnego, podczas gdy dane zachowanie może być tylko naganne z punktu widzenia etycznego i nie stanowić realizacji znamion jakiegokolwiek czynu zabronionego ${ }^{35}$. Brak zastrzeżenia, że konieczne jest zrealizowanie wszystkich znamion czynu zabronionego jednocześnie skutkuje również powstaniem medialnego czy społecznego domniemania winy, podczas gdy pod względem prawnym brak jest podstaw do przyjęcia zarzucalności realizacji wszystkich znamion czynu zabronionego. Dla wzmocnienia zainteresowania przekazem, który

${ }^{34}$ Jeżeli chodzi o podstawy faktyczne, to trzeba zauważyć, że w ramach medialnego populizmu wytworzył się stan rzeczy niebezpieczny, w którym odchodzi się od przedstawiania faktów, a przyjmuje tylko ich interpretacje. Powstaje zjawisko postprawdy, o którym pisze D’Ancona $(2018,111)$.

${ }^{35}$ Marek, Konarska-Wrzosek $(2019,140)$, gdzie jasno wskazano, że wina jest relatywizowana do czynu zabronionego, co oznacza, że chodzi o tzw. winę prawną, a nie o ujemny tryb życia osoby czy niebezpieczeństwo osobowości sprawcy. Wynika to jasno z zasad wskazanych w treści art. 1 $\S \S 1-3$ kodeksu karnego. 
jest kierowany do odbiorcy, może dochodzić także do nadmiernego używania określeń przymiotnikowych (ocennych), które nie należą do znamion czynu, a jeżeli zachowanie cechuje się intensywnością, która nie jest jednocześnie znamieniem czynu, to może mieć wpływ na wymiar kary w ramach sądowego wymiaru kary. Takie postępowanie bez wyjaśnienia i przedstawienia motywacji może prowadzić do publicznego osądzenia, zanim zapadnie prawomocny wyrok. Domniemanie winy może również być skierowane do niewłaściwej osoby, z pominięciem informacji odnoszących się do osoby, która spełnia warunki bycia podmiotem odpowiedzialnym na naruszenie przepisów prawa karnego i wypełnienia znamienia czynu zabronionego ${ }^{36}$. Odchodzenie od personalizacji prawa $\mathrm{w}$ kierunku prawa pozytywnego i odbieranie uwzględnienia wszystkich okoliczności dotyczących osoby jest nie tylko niezgodne z obowiązującym prawem nakazującym uwzględnienie okoliczności osobistych, ale także niebezpiecznym kierunkiem, który odbiera uprawnionym organom bycie partnerami ustawodawcy w procesie urzeczywistniania prawa ${ }^{37}$. W konsewencji prowadzić może do ustawowego bezprawia (Zajadło 2016, 16 i n.).

Odrzucenie domniemania niewinności i przyjęcie domniemania winy związane jest także z kształtowaniem pozycji organów wymiaru sprawiedliwości, jakimi są sądy i niekiedy mylne informowanie, że do organów tych zaliczana jest prokuratura, które przecież nie posiada uprawnień orzeczniczych w zakresie ustalania sprawstwa i winy. Marginalizowanie pozycji sądów i nieuprawnione przesuwanie kompetencji orzeczniczych na wcześniejsze etapy prowadzenia postępowania skutkuje tym, że dochodzi do przypisania sprawstwa czynu poza organem uprawnionym do orzekania $\mathrm{w}$ tym zakresie, a mianowicie sądem.

Można także zaobserwować małą ilość informacji o wyrokach skazujących za popełnienie tzw. „,przestępstw gospodarczych”. Podstawy tego stanu rzeczy mogą być różne, w tym brak przedstawienia istoty tych czynów zabronionych, skomplikowanie materii faktycznej, dowodowej i prawnej, a ponadto zapewne niecierpliwość w oczekiwaniu na wydanie wyroku, często po długim czasie. Informacje medialne, które dotyczą wyroków skazujących odnoszą się głównie do czynów zabronionych, skierowanych przeciwko życiu i zdrowiu. Brak uzasadnienia dotyczyć może także decyzji podejmowanych na wcześniejszych etapach postępowania w postaci postanowienia o odmowie wszczęcia postępowania przygotowawczego lub postanowienia o umorzeniu postępowania przygotowawczego.

${ }^{36}$ Przykładem takiego postępowania może być pominięcie funkcjonariusza publicznego, który przyznaje wysokie wynagrodzenie pracownikowi i skupienie się na zarzucie przyjęcia takiego wynagrodzenia przez pracownika, który nie ma statusu funkcjonariusza publicznego i nie może być podmiotem odpowiedzialności, a ponadto brak uwagi na czynności sprawcze, które polegają na przekroczeniu uprawnień w zakresie przyznania wynagrodzenia.

${ }^{37}$ Zajadło $(2018,102)$, gdzie autor wskazuje na rolę sędziego, który ma normę abstrakcyjnogeneralną przekształcić w słuszne prawo, a nie ustawowe bezprawie. 
Trzeba jeszcze zwrócić uwagę na korzystanie z różnego rodzaju ekspertów, którzy wypowiadają się w sprawach dotyczących prowadzonych spraw karnych i ich rolę w kształtowaniu domniemania niewinności ${ }^{38}$. W tym miejscu należy zastrzec, że eksperci ci posiadają tylko szczątkowe i to najcześciej pochodzące ze środków masowego przekazu informacje, które dotyczą omawianego problemu, co oznacza, że nie mają pełnej wiedzy o postępowaniu i zgromadzonych dowodach, które pochodziłyby z akt prowadznego postępowania przygotowawczego. Symptomatyczne jest to, że, pomimo aktualności tej problematyki, brak jest nowych badań socjologicznych. Starsze badania pokazują, że przekazywane informacje nie są obiektywne, mieszczą aż w prawie $70 \%$ oceny, a w sprawach karnych aż 48\% spośród nich zawierało komentarz ${ }^{39}$. Przy rosnącym natłoku informacji, zrozumiałym braku wiedzy fachowej oraz skomplikowanym przekazie danych zachodzi prawdopodobieństwo, że udostępnione z komentarzem dane zostaną przyjęte w całości. Jeżeli chodzi o odbiór społeczny upublicznionych informacji, to już dawno wykazano, iż dominuje skłonność do posłuchu dla plotek oraz szybszego akceptowania ujemnych sądów ${ }^{40}$. Jeżeli uwzględnić zwiększające się tempo we wszystkich obszarach oraz oczekiwanie skracania przekazu przy jednoczesnym podnoszeniu poziomu emocjonalnego informacji, to brak jest powodów, aby uznać, że doszło do polepszenia sytuacji w zakresie realizacji zasady domniemania niewinności. Sytuacji nie polepsza fakt korzystania ze środków szybszego przekazu w postaci Internetu. Zupełnie nowym zjawiskiem, które, jak się wydaje, nie było przedmiotewm żadnych badań, jest możliwość kształtowania nastawienia do danej osoby w świetle realizacji zasady domniemania niewinności, na podstawie cudzych komentarzy oraz możliwości zaprezentowania osobistego stanowiska.

Wszystkie te uwagi prowadzą do wniosku, że niezwykle ważne jest rzetelne przekazywanie informacji, aby nie stworzyć medialnego oraz społecznego domniemania winy.

\section{SKUTKI NARUSZENIA ZASADY DOMNIEMANIA NIEWINNOŚCI}

Naruszenie zasady domniemania niewinności pociąga za sobą wielorakie skutki, które dotykają różnych sfer życia osoby, wobec której to domniemanie niewinności zostało naruszone. Chodzi tutaj przede wszystkim o skutki

${ }^{38}$ Zajadło (2008, 54), gdzie wprawdzie mowa jest o ekspertach w procesie tworzenia prawa, ale niebezpieczne zjawisko tzw. „eksperta dworskiego”, który według Wronkowskiej (2000, 12), powoływany jest, by podjętą decyzję przekonywająco uzasadnić, a nie dostarczyć przesłanek intelektualnych dla jej powzięcia, przy czym zjawisko tzw. ekspertów dworskich może być odnoszone do procesu informowania opinii publicznej o prowadzonych sprawach w kontekście zasady domniemania niewinności.

${ }^{39}$ Miarczyński $(2013,340)$, powołując się na badania przeprowadzone w latach 19881990 i opublikowane u Błachuta (Błachut 1997, 73, 92).

${ }^{40}$ Waltoś $(2009,8)$ z powołaniem na Thiele-Dohrmann (1980). 
oszczerczego zarzutu, które karane były już od czasów Pierwszej Rzeczpospolitej nie tylko karą pieniężną, ale także odwołaniem zniewagi, które polegało na tym, że oszczerca wypowiadał słowa „To cóżem uczynił, zełgałżem jako pies" (Bardach, Leśnodorski, Pietrzak 2009, 186). Oszczerca wchodził pod ławę i oszczerstwo odszczekiwał trzykrotnie „psim głosem” (Bardach, Leśnodorski, Pietrzak 2009, 186).

Obecnie z domniemaniem niewinności powiązany jest nie tylko nakaz traktowania danej osoby jako niewinnej, ale także nakaz udowodnienia winy przez oskarżyciela publicznego. Na oskarżonym nie spoczywa ciężar dowodu (Kardas 2017, 53 i n.), z tym jednak, że przy zniesławieniu z art. 212 k.k. prawo karne zakłada wyłączenie przestępności zachowania w warunkach wskazanych w art. 213 k.k. ${ }^{41}$

Rozważenia wymaga także naruszenie zasady domniemania niewinności w kontekście nie tylko prawdy filozoficznej, ale także naruszenia godności człowieka jako jednego z przyrodzonych i nienaruszalnych praw przynależnych człowiekowi. Już Arystoteles powiedział, że „, [k]to twierdzi o czymś, że istnieje albo, że nie istnieje, powie prawdę albo fałsz"42. Odwołał się więc do przedstawienia faktów zgodnie z rzeczywistością, jeżeli są prawdziwe lub niegodnie z rzeczywistościa, jeżeli nie miały one miejsca. Również Erich Fromm uważa, że „sumienie jest tak samo niepodzielne jak prawda" (Fromm 2018, 176). Z przytoczonego cytatu Arystotelesa oraz Ericha Fromma jasno wynika, że określone stwierdzenie nie może być jednocześnie prawdziwe lub fałszywe. Nie można więc twierdzić, że dana osoba jest jednocześnie objęta domniemaniem niewinności i jest winna. Jako że godność człowieka przynależy mu z samego faktu bycia człowiekiem, jest niezbywalna, to oznacza, że nikt nie może jej pozbawić człowieka i obejmuje ona przykładowo pozytywne obowiązki państwa wobec jednostki chroniące ją przed mobbingiem w miejscu pracy (Brzozowski, Krzywoń, Więcek 2018, 119), to zasadne wydaje się uznanie, że złamanie zasady domniemania niewinności także narusza godność człowieka.

Na gruncie prawa cywilnego pozostaje ochrona dóbr osobistych gwarantowana na podstawie art. 23 k.c. i 24 k.c. Trzeba jednak zwrócić uwagę na specyficzną sytuację sądu cywilnego, jeżeli jenocześnie toczy się postępowanie karne, ponieważ nie może on samodzielnie rozstrzygać, czy powód jest winny popełnienia przestępstwa, które zostało mu zarzucone ${ }^{43}$. W wyroku z 12.10.2011 r., I ACa 326/11 Sąd Apelacyjny słusznie wskazał, że „,podanie przez pozwanego nieprawdziwych informacji nie może być uznane za działanie w ochronie uzasadnionego interesu społecznego albowiem wyłączenie bezprawności postępowania dotyczy

${ }^{41}$ Grzegorczyk $(2014,61)$; Safjan, Bosek $(2016,1067)$ i powołany tam wyr. ETPC z 14.06.2011 r., w sprawie Garlicki przeciwko Polsce, skarga nr 36921/07.

${ }^{42}$ Gadacz $(2014,99)$, gdzie wskazany cytat pochodzi z Metafizyki Arystotelesa.

${ }^{43}$ Świecki $(2013,48)$ i powołany tam wyr. SA w Warszawie z 12.10.2010 r., I ACa 326/11, OSA 2012, nr 8, poz. 45-64. 
tylko przypadku podania informacji prawdziwych"44. Abstrahując od pojęcia prawdy (Zajadło, Zeidler 2013, 293 i n.; Zajadło 2017, 241 i n.), trzeba przyznać, iż stwierdzenie to, choć oczywiste, nie zawsze znajduje praktyczne zastosowanie, szczególnie tam, gdzie w grę wchodzą polityczne względy swoiście pojętego interesu społecznego.

$\mathrm{Na}$ gruncie prawa prasowego do wykorzystania pozostaje procedura sprostowania informacji, które zostały opublikowane, ale jest to narzędzie daleko niedoskonałe, ponieważ obarczone długim oczekiwaniem i po jego opublikowaniu odbiorca nie jest w stanie wskazać, z jakim zdarzeniem było ono związane.

W jednym ze swoich orzeczeń Europejski Trybunał Praw Człowieka stwierdził, że uniewinnienie nie zwalnia od badania naruszenia art. 3 Europejskiej Konwencji Praw Człowieka ${ }^{45}$. Ponadto przyjmuje się, że w procesach dotyczących naruszenia czci osób, co do których wszczęte zostało postępowanie karne, wystarczające jest respektowanie zasady domniemania niewinności i rzetelnego procesu karnego ${ }^{46}$.

Wydaje się jednak, że kwestia domniemania niewinności dotyczy nie tylko osoby, do której się ona odnosi, ale także sięga głębiej i dotyka przekazu prawdy ${ }^{47}$ opinii publicznej, a także - co równie ważne - kształtuje i buduje zaufanie do instytucji, która te informacje przekazuje lub też je niweczy, jeżeli udzielanie informacji ma na celu wywołanie krótkotrwałego zamierzonego efektu ${ }^{48}$. Przekaz prawdy dotyczy nie tylko danego zdarzenia jako takiego, ale rówież danych dotyczących stwierdzonych przypadków określonego zdarzenia, danych porównawczych na osi czasu, także z innymi krajami, dla właściwego zobrazowania danego zjawiska.

Trzeba także podkreślić, że budowa zaufania do instytucji winna być rozpatrywana w szerszym kontekście ich współpracy z odpowiednimi instytucjami w ramach tak ważnych problemów, jak bezpieczeństwo międzynarodowe,

${ }^{44}$ Wyr. SAw Warszawie z 12.10.2011 r., I ACa 326/11, LEX nr 1120113.

${ }^{45}$ Nowicki $(2013,420)$ i powołany tam wyr. Ivan Vasilev przeciwko Bułgarii z 12.04.2007 r., Izba (Sekcja V), skarga nr 48130/99, § 64, wyr. Colak i Filizer przeciwko Turcji z 8.01.2004 r., Izba (Sekcja III), skarga nr 32578/96 i 32579/96, § 33, wyr. Dedovskiy i inni preciwko Rosji z 15.05.2008 r., Izba (Sekcja I), skarga nr 7178/03, § 98.

${ }^{46}$ Brzozowski, Krzywoń, Więcek $(2018,184)$ i powołany tam wyr. TK z 17.12.2003 r., SK $15 / 02$.

${ }^{47}$ Brzozowski, Krzywoń, Więcek $(2018,185)$ i powołany tam wyr. ETPCz z 8.07.1986 r., nr skargi 9815/82, Lingens przeciwko Austrii oraz SN z 5.04.2002 r., II CKN 1095/99, z których wynika, że w żadnym wypadku nie można publikować nieprawdy, ani nierzetelnie wykorzystywać materiałów prasowych.

${ }^{48}$ Zajadło $(2016,45)$, gdzie autor pisze, że siostrą sprawiedliwości jest prawda. Autor wskazuje także na to, że do praktyk narodowo-socjalistycznych należało używanie słów w sposób jawnie sprzeczny ze stanem rzeczy i jako przykład wskazuje, że ustawa z 7.04 .1933 r., która miała zwalniać i ponownie obsadzać na stanowiskach urzędniczych po linii partyjnej, została nazwana Ustawą o odnowie profesji urzędniczej (RGB 1, I, 175). 
terroryzm, uznawanie i wykonywanie orzeczeń. Trzeba też zwrócić uwagę na to, że zaufanie do instytucji jest budowane przez konkretne osoby, które winny jako swój obowiązek uznawać przekazywanie tylko zgodnych z prawdą informacji.

\section{WNIOSKI KOŃCOWE}

Informacja o obowiązującym prawie i kompetencjach odpowiednich organów pełni istotną rolę w społeczeństwie, ponieważ kształtuje wyobrażenie o systemie prawa. Kształtuje ona także osąd społeczny przedstawionej sprawy. Ważną rolę odgrywa język, jakim posługują się dziennikarze w informowaniu społeczenstwa o konkretnych sprawach. Używanie przymiotników jako stopniowania czynności wskazanej osoby ma wywołać zamierzony efekt u odbiorcy, ale $\mathrm{z}$ prawnym rozumieniem czynu zabronionego nie ma w większości wypadków nic wspólnego ${ }^{49}$. Tak przekazana informacja wypacza rozumienie istoty czynu zabronionego i może doprowadzić do uznania za karalne takich zachowań, które w rzeczywistości nimi nie są, szczególnie tam, gdzie wchodzi w grę pozaprawny, inny, w tym polityczny, interes.

Na przyjęcie domniemania winy mają wpływ informacje o wszczęciu postępowania przygotowawczego, wykonywanych czynnościch procesowych, wydaniu postanowienia o przedstawieniu zarzutów określonym osobom, kierowaniu aktów oskarżenia bez właściwego zaznaczenia, że dopiero prawomocne orzeczenie skazujące przełamuje domniemanie niewinności. Wskazane wyżej przykłady mogą rodzić domniemanie winy, zamiast właściwie kształtowanego domniemania niewinności. Rzetelne informowanie o rodzaju, ilości popełnionych czynów zabronionych ma również przesądzające znaczenie o poziomie przestępczości w określonym odcinku czasowym oraz na określonym obszarze $^{50}$. Daje również podstawy do właściwej oceny przyczyn przestępczości i zastosowania odpowiednich środków do jej zmniejszenia, przy czym pozwala spojrzeć na zjawisko przestępczości nie tylko z punktu widzenia karnego, ale także społecznego i zastosować środki pozakarne do ograniczania czynników

${ }^{49} \mathrm{~W}$ znamionach większości czynów zabronionych brak jest nośnika emocjonalnego. Wyjątek stanowią niektóre czyny zabronione, które skierowane są przeciwko życiu i zdrowiu, przykładowo art. $148 \S 2$ pkt 3 k.k., gdzie ustawodawca dokonał stopniowania motywacji, wskazując, że chodzi o motywację zasługującą na szczegołne potępienie.

${ }^{50}$ Krytycznie należy ocenić przedstawianie określonej kategorii spraw lub określonej kategorii sprawców, bez odwołania się do przedstawienia całościowych danych co do ilości danej kategorii przestępstw w przeliczeniu na przyjęty współczynnik populacji lub też bez odniesienia do odcinka czasu pozwalającego na ustalenie tendencji spadkowej lub wzrostowej co do wybranej kategorii przestępstw lub określonej kategorii sprawców. 
inicjujących popełnianie czynów zabronionych ${ }^{51}$. Zasada domniemania niewinności powiązana jest również z kształtowaniem zaufania społecznego do instytucji, ale także z budowaniem takiego zaufania w ramach współpracy międzynarodowej. Tak więc skutki właściwego podejścia do zasady domniemania niewinności mogą się odnosić nie tylko do obszaru prawa karnego, ale mieć także wielopłaszczyznowy wydźwięk społeczny i międzynarodowy. Wydaje się, że funkcjonująca $w$ prawie zasada domniemania niewinności nie znajduje odpowiedniego dla niej miejsca w medialnym przekazie. Brak jasnego podkreślenia tej zasady skutkuje w społecznym odbiorze uproszczeniami i formułowaniem kategorycznych i prostych rozwiązań, które w rzeczywistości nie posiadają przymiotu efektywności. W zmieniającym się coraz szybciej świecie i natłoku informacji ważne jest, aby były one prawdziwe. Na ich podstawie kształtowany jest nie tylko obraz jednostki i nastawienie do niej, ale także funkcjonowanie organów ścigania oraz wymiaru sprawiedliwości. Problem szczególnie wybrzmiewa w sytuacjach kryzysowych, kiedy istnieje pokusa poświęcenia zasady domniemania niewinności dla osiągnięcia doraźnych celów, przy jednoczesnym niszczeniu celów długoterminowych w postaci zaufania do państwa, jego organów oraz zasadności i celowości podejmowanych przez nie czynności.

Na koniec trzeba jeszcze raz podkreślić, że prawidłowo realizowana przez właściwe organy oraz osoby zasada domniemania niewinności ma wpływ na kształowanie się poziomu kultury prawnej społeczeństwa.

\section{BIBLIOGRAFIA}

D’Ancona, Matthew. 2018. Postprawda. Warszawa: Wydawnictwo Krytyki Politycznej.

Bardach, Juliusz. Bogusław Leśnodorski. Michał Pietrzak. 2009. Historia ustroju i prawa polskiego. Warszawa: LexisNexis.

Bojarski, Tadeusz. Red. 2011. Źródła prawa karnego. System Prawa Karnego. Tom 2. Warszawa: C.H. Beck, Instytut Nauk Prawnych PAN.

Boratyńska, Katarzyna. Adam Górski. Andrzej Sakowicz. Andrzej Ważny. 2009. Kodeks postępowania karnego. Warszawa: Wydawnictwo C.H. Beck.

Brzozowski, Wojciech. Adam Krzywoń. Marcin Więcek. 2018. Prawa człowieka. Warszawa: Wolters Kluwer.

Dukiet-Nagórska, Teresa. 2018. Prawo karne. Część ogólna szczególna i wojskowa. Warszawa: Wolters Kluwer.

${ }^{51}$ Trzeba pamiętać o tym, że najbardziej miarodajnym wskaźnikiem liczby popełnionych czynów zabronionych będą dane uzyskane z etapu prawomocnych orzeczeń sądowych, ponieważ dotyczą one stwierdzenia popełnienia czynu zabronionego. Statystyki, które zostały uzyskane z wcześniejszych etapów postępowań, mogą nie być tutaj tak wiarygodne, ponieważ podstawą zakończenia postępowania może być przykładowo stwierdzenie, że czynu nie popełniono (art. 17 $\S 1$ pkt 1 k.p.k.) lub czyn nie zawiera ustawowych znamion czynu zabronionego (art. $17 \S 1$ pkt 2 k.p.k.). 
Fromm, Erich. 2018. O miłości do życia. Meandry kultury. Kraków: Vis-à-vis etiuda.

Gadacz, Tadeusz. 2018. Uniwersalne prawdy i prawa życia dla madrych ludzi na trudne czasy. [Warszawa]; [Siedliska]: Wydawnictwo Nieoczywiste.

Garlicki, Leszek. Red. 2003. Konstytucja Rzeczypospolitej Polskiej. Komentarz. Tom III. Warszawa: Wydawnictwo Sejmowe.

Grzegorczyk, Tomasz. 2014. Kodeks postępowania karnego. Tom I. Wydanie 6. Warszawa: Lex a Wolters Kluwer business.

Kardas, Piotr. 2017. „Determinanty ciężaru dowodu i ciężaru (obowiązku) dowodzenia w procesie karnym". W Ciężar dowodu i obowiazek dowodzenia w procesie karnym. 53-120. Red. Wojciech Jasiński, Jerzy Skorupka. Warszawa: Wolters Kluwer.

Krztoń, Waldemar. 2018. Godnośc ludzka jako istotna wartość bezpieczeństwa jednostki. Warszawa: Rambler Press.

Kulesza, Witold. 2012. Przestepstwa przeciwko dobrom indywidualnym. System Prawa Karnego. Red. Jarosław Warylewski. Tom 10. Warszawa: Wydawnictwo C.H. Beck, Instytut Nauk Prawnych PAN.

Marek, Andrzej. Violetta Konarska-Wrzosek. Red. 2019. Prawo karne. Warszawa: Wydawnictwo C.H. Beck.

Miarczyński, Michał. 2013. „Zasada domniemania niewinności i jej realizacja w polskiej prasie”. Zeszyty Prasoznawcze 56(3): 335-349. http://cejsh.icm.edu.pl/cejsh/element/bwmeta1. element.ojs-issn-2299-6362-year-2013-volume-56-issue-3-article-4796 [dostęp: 28.03.2020].

Nowicki, Marek Antoni. 2013. Wokót Konwencji Europejskiej. Komentarz do Europejskiej Konwencji Praw Człowieka. Warszawa: Lex a Wolters Kluwer business.

Paprzycki, Lech. Red. 2013. Kodeks postępowania karnego. Komentarz Lex. Tom I. Wydanie 3. Warszawa: Lex a Wolters Kluwer business.

Safjan. Marek. Leszek Bosek. Red. 2016. Konstytucja RP. Tom I. Warszawa: Wydawnictwo C.H. Beck.

Skorupka, Jerzy. Red. 2015. Kodeks postępowania karnego. Komentarz. Warszawa: Wydawnictwo C.H. Beck.

Świecki, Dariusz. Red. 2013. Kodeks postępowania karnego. Wydanie 1. Warszawa: LexisNexis.

Thiele-Dohrmann, Klaus. 1980. Psychologia plotki. Warszawa: Państwowy Instytut Wydawniczy.

Waltoś, Stanisław. 2009. „Konstytucyjna zasada domniemania niewinności a środki masowego przekazu". Nauka 1: 7-22. https://prawo.uni.wroc.pl/sites/default/files/students-resources/ zasada $\% 20$ domniemania $\% 20$ niewinno $\%$ C 5\%9Bci $\% 20$ a $\% 20 \%$ C $5 \% 9$ Brodki $\% 20$ masowego\%20przekazu\%20.pdf [dostęp: 28.03.2020].

Wronkowska, Sławomira. 2000. „Ekspert a proces tworzenia prawa”. Państwo i Prawo 9: 3-15.

Wróbel, Andrzej. Red. 2013. Karta Praw Podstawowych Unii Europejskiej. Warszawa: Wydawnictwo C.H. Beck.

Zajadło, Jerzy. 2008. Po co prawnikom filozofia prawa? Warszawa: Wolters Kluwer Polska.

Zajadło, Jerzy. 2016. Radbruch. Sopot: Wydawnictwo Arche.

Zajadło, Jerzy. 2018. Kaufamnn. Sopot: Wydawnictwo Arche.

Zajadło, Jerzy. Red. 2017. Leksykon wspótczesnej teorii i filozofii prawa. Wydanie 2. [Zmienione i uaktualnione]. Warszawa: Wydawnictwo C.H. Beck.

Zajadło, Jerzy. Kamil Zeidler. 2013. Filozofia prawa w pytaniach $i$ odpowiedziach. Wydanie 1. Warszawa: LexisNexis.

\section{Akty prawne}

Kodeks postępowania karnego z 19.03.1928 r. - t.j. Dz.U. 1949.33.243 ze zm.

Konwencja o Ochronie Prawa Człowieka i Podstawowych Wolności, sporządzona w Rzymie 4.11.1950 r., zmieniona następnie Protokołami nr 3, 5 i 8 oraz uzupełniona Protokołem 
nr 2, - Dz.U. z 1993 r., nr 61, poz. 284; http://prawo.sejm.gov.pl/isap.nsf/download.xsp/

WDU19930610284/O/D19930284.pdf [dostęp: 30.05.2019].

Międzynarodowy Paktu Praw Obywatelskich i Politycznych, otwarty do podpisu w Nowym Jorku 19.12.1966 r. - Dz.U. z 29.12.1977 r. - Dz.U. 1977.38.167. zał.

Powszechna Deklaracja Praw Człowieka, uchwalona 10.12.1948 r. na Trzeciej Sesji Ogólnej Zgromadzenia ONZ; http://www.unesco.pl/fileadmin/user_upload/pdf/Powszechna_Deklaracja

Praw_Czlowieka.pdf [dostęp: 30.05.2019].

Ustawa z 19.04.1969 r. - Kodeks postępowania karnego - Dz.U. z 14.05.1969 r. - Dz.U. 1969.13.96.

Ustawa z 26.01.1984 r. Prawo prasowe - t.j. Dz.U. 2018.1914.

Ustawa z 6.06.1997 r. Kodeks karny, t.j. Dz.U. z 2018 r., poz. 1600 ze zm.

Ustawa z 6.06.1997 r. Kodeks postępowania karnego - t.j. Dz.U. 2018.1987.

\section{Decyzje}

Decyzja Komisji F. i S. F. v, Austria z 7.10.1985 r., skarga nr 10847/84, DR 44/238.

Decyja Komisji Petra Krauze v. Szwajcaria z 3.10.1978 r., skarga nr 7986/77, DR 13/73.

Decyzja Komisja X. v. Holandia z 17.12.1981 r., skarga nr 8361/78, DR 27/37.

\section{Orzecznictwo}

Orzeczenie Allenet de Ribemont v. Francja z 10.02.1995 r., A. 308, par. 38.

Orzeczenie Beelen v. Belgia z 24.02.1997 r., skarga nr 25470/94, nie publ.

Postanowienie SA w Krakowie z 29.11.1999 r., II AKz 537/99, KZS 1999, nr 12, poz. 25.

Wyrok Ashot Harutynyan przeciwko Armenii z 15.06.2010 r., Izba (Sekcja III), skarga nr 34334/04. Wyrok Colak i Filizer przeciwko Turcji z 8.01.2004 r., Izba (Sekcja III), skarga nr 32578/96 i 32579/96. Wyrok Dedovskiy i inni preciwko Rosji z 15.05.2008 r., Izba (Sekcja I), skarga nr 7178/03.

Wyrok ETPC z 25.03.1983 r., 8660/79, Minelli przeciwko Szwajcarii, LEX nr 80843.

Wyrok ETPC z 8.07.1986 r., skarga nr 9815/82, Lingens przeciwko Austrii.

Wyrok ETPC z 14.06.2011 r., w sprawie Garlicki przeciwko Polsce, skarga nr 36921/07.

Wyrok Ivan Vasilev przeciwko Butgarii z 12.04.2007 r., Izba (Sekcja V), skarga nr 48130/99.

Wyrok Konstas v. Grecja z 24.05.2011 r., Izba (Sekcja I), skarga nr 53466/07.

Wyrok Pizuryna przeciwko Armenia z 26.06.2012 r., Izba (Sekcja III), skarga nr 33376/07.

Wyrok SA w Warszawie z 12.10.2010 r., I ACa 326/11, OSA 2012, nr 8, poz. 45-64.

Wyrok SN z 5.04.2002 r., II CKN 1095/99.

Wyrok SN z 6.06.2006 r., IV KK 87/06, OSNKW 2006, nr 10, poz. 91.

Wyrok SN z 6.12.2006 r., III KK 181/06 (OSNKW 2007, nr 2, poz. 16).

Wyrok SPI z 6.10.2005 r., T-22/02 oraz T-23/02, Sumitomo Chemical Co. Ltd. i Sumika Fine Chemicals Co. Ltd. przeciwko Komisji Wspólnot Europejskich, Zb. Orz. 2005, II-4065, pkt. 106-107.

Wyrok TK z 17.12.2003 r., SK 15/02.

Wyrok Y.B. i inni v. Turcja z 28.10.2004 r., Izba (Sekcja III), skarga nr 48173/99 i 48319/99, § 47-48.

Wyrok z 27.01.2009 r., Izba (Sekcja IV), skarga nr 1704/06.

Wyrok z 20.01.2011 r., Izba (Sekcja V), skarga nr 891/05. 


\title{
Krystyna Patora
}

\section{MEDIA AND SOCIAL PRESUMPTION OF GUILT AND THE LEGAL GUIDANCE OF INNOCENCE (LEGAL LOOK AND A NEW PERSPECTIVE)}

\begin{abstract}
The topic of the article are the considerations which regard the obligatory in the penal code presumption of innocence as well as the presumption of guilt, which may arise in the media thereby in the public opinion. Legal solutions in criminal law, press law and international law have been discussed to counteract the creation of a false picture of processes. In addition, judicial decisions have been pointed out, which set the requirements for reliable information on the course of preparatory and court proceedings, as well as special attention paid to spokespersons.
\end{abstract}

Keywords: principle of presumption of innocence, media presumption of guilt, social presumption of guilt, suspect, suspect, accused, convicted, final conviction. 